\section{Volcanological Research in Britain}

ON behalf of the Volcanological Research Committee of the Royal Society, the terms of reference of which are "to encourage, promote and co-ordinate the comprehensive study of volcanicity . . .", a booklet has been published to record the scope of researches being undertaken at presont by universities and other scientific institutions in Britain on modern and ancient voleanoes (United Kingdom Volcanological Research, 1965. A summary of current volcanological studies with provisional plans for future years. Pp. 55. London: The Royal Society, 1965). The extent of the studies recorded is wide, embracing work at about a hundred localities outside the British Isles, described in close on 150 recent papers (inclusive of some reports of researches in experimental petrology). It is hoped to publish a further edition of the booklet in about two years' time when attention will be restricted to current investigations on Tertiary and Recent volcanicity.

\section{Age Determinations of North American Rocks}

A comprlation of the radiometric ages determined for rocks of the North American continent, complete up to May 1964, has recently been published by the Com. mittee on Nuclear Science of the National Academy of Sciences-National Research Council in Washington (Publication 1276: Geochronology of North America. Nuclear Science Series-Report No. 41. Pp. v+315. Washington, D.C.: National Academy of SciencesNational Research Council, 1965. 6 dollars). In it, a brief introduction to the present status of geochronological methods, by Dr. G. W. Wetherill, is followed by a 270-page tabulation of results listed on a regional basis and by a bibliography of 144 items. The oldest well-dated rocks in North America bear ages of about 2,500-2,800 million years, and are found in an apparently continuous belt extending from Quebec through Ontario, Manitoba, Minnesota, North Dakota, Montana, and into Wyoming, as well as in the Great Slave Lake area of the North-West Territory. They are apparently much younger than the most ancient formations of southern Africa and of arctic Russia. Extensive recent data supplementary to the results in the American compilation have been published contemporaneously by the Geological Survey of Canada and are accompanied by a report by Dr. C. H. Stockwell which proposes a new time-stratigraphic classification and nomenclature for the rocks of the Canadian shield (Paper 64-17. Parts I and II. Age Determinations and Geological Studies. (I) Pp. iv +126.75 cents. (II) Pp. iv +29 . 75 cents. Ottawa: Queen's Printer, 1965). In this, the Archaean and Proterozoic are each identified as eons, with the latter divided into the Aphebian, Helikian (Palaeohelikian and Neohelikian) and Hadrynian eras, the lower boundaries of which are respectively marked by the Kenoran (2,390 m.y.), Hudsonian (1,640 m.y.; Elsonian at ?1,280 m.y.), and Grenville (880 m.y.) orogenies.

\section{Soil Micro-fauna}

THe formation of humus is a most important matter to foresters, not only because it helps to maintain proper conditions for tree growth, but also because it may bring about improvements to the quality of the trees and give greater productivity to the site. A big part is played by oribatids in the breakdown of the litter and its conversion into humus, and members of this super-family of the Acarinae occur in very large numbers in the soil fauna. In Contribution à l'Etude Ecologique des Oribates de la Litière dans une Forêt de Moyenne-Belgique, by Philippe Lebrun, we not only have an example of a very fine pieco of research carried out in 13 months of field work, but also results presented in a full and yet concise manner, and set out with proper reference to the other factors affecting the biocenose (Institut Royal des
Sciences Naturelles de Belgique. Memoire No. 153. Pp. 96. Bruxelles: Institut Royal des Sciences Naturelles de Belgique, 1965). The published account is divided into three chapters. The first is an account of the locality factors. The research was carried out in an oak-wood on the south-eastern slopes of a small valley near Louvain in central Belgium in 1961-62. Information is given of the vegetation, soil, local climate, the water-holding capacity of the soil and the evapotranspiration. The second chapter is devoted to the synecology of the oribatids with the view of discovering the bonds existing between different groups of them. The final chapter deals with the autecology of the oribatids found on the site. The forester recognizes the great importance of these minute members of the animal kingdom, but it is not always remembered in what quantitios they occur. In a Belgian oak-wood it is estimated that there are about 75,000 individuals per square metre of the upper soil and humus layers and even up to as many as 300,000 per square metre. Thus, their numbers alone present some difficulty to the research worker who, in this case, had to contend with 48 species in a sample population of 85,000 individuals. Philippe Lebrun has not only clearly described his fine piece of research but he has also taken into consideration, as is very proper but not always done, the various factors of the vegetation, soil and climate which contribute to the biocenose. Thus, the danger in such a work of omitting some important factor affecting: the result has been avoided. The numerous histograms and graphs make for easy understanding of the various components of the investigation. Nothing seems to have been forgotten: for example, there is a histogram showing the precipitation reaching the soil compared with the actual precipitation. This is but one example of the detail to be found in a work which will be acclaimed by foresters and others interested in the soil micro-fauna.

\section{Oil Pipeline over the Alps}

IT may not be generally realized that work is in progress on the colossal project of constructing a 40 -in. diameter, 300 miles long, Trans-Alpine oil pipeline to convey oil from the Adriatic to the heart of Germany, as so far this scheme has received relatively little publicity. To a brief extent, this has now been remedied by an article entitled "Pipeline Over the Alps" (Esso Magazine, Esso Petroleum Company, London, Summer 1965). The route lies from Trieste, by Udine, Lienz, Kitzbuhel, Kufstein, Rosenheim., east of Munich to Ingolstadt. It necessitates the construction of three tunnels under the Alps, one known as the Plöcken Tunnel, between Udine and Lienz; one known as the Felber Tauern Tunnel, and another as the Hahnenkamm Tunnel, both between Lienz and Kitzbuhel. These are indeed major engineering feats in themselves, and the photographic illustrations included in the article, together with a panoramic map in colour, make this abundantly clear. This project will ultimately include the construction of a branch pipeline just north of the Plöcken Tunnel to link up with the Austrian State Refinery near Vienna. The Trans-Alpine pipeline is a venture in which several oil companies are taking part and in which the Esso Petroleum Company has the largest interest. However, because the pipeline has to pass through three separate countries, three separate companies have been formed for constructional and operational purposes in their respective areas. These companies are Deutsche Trans-Alpine Oelleitung G.m.b.H., Trans-Alpine Oelleitung in Osterreiche G.m.b.H., and Società Italiana per L'Oleodotto Trans-Alpino S.p.A. The German company is the co-ordinating company. Among the many practical problems concerned with such a project, apart from tunnelling and mochanical excavation in the high Alps, are the necessity to dredge the harbour at Trieste so that it can eventually accommodate oil tankers of 160,000 dead. weight tons; setting storage tanks there on piles because 